\title{
НОСТАЛГИЧНИ ВРЪЗКИ, ЕТНОКУЛТУРНА ИДЕНТИФИКАЦИЯ И ЕВРОИНТЕГРАЦИОННИ ВЪЗГЛЕДИ СРЕД УКРАИНСКИ МИГРАНТИ В ОБЩИНА СЛИВЕН В БЪЛГАРИЯ
}

\author{
T. С. Матанова
}

\begin{abstract}
Матанова T. C. Носталгични връзки, етнокултурни идентификация и евроинтеграциони възгледи сред украински мигранти в община Сливен в България. В статията се разглеждат езиковите, музикалните, родовите, хранително-вкусовите и предметните носталгични връзки на украински мигранти, както и етнокултурните и други самоидентификации на украински мигранти в община Сливен в България. В допълнение са представени и някои мнения на анкетираните относно влизането на Украйна в Европейския съюз.

Ключови думи: украински мигранти; носталгични връзки; самоидентификация; Украйна в Европейския съюз.
\end{abstract}

Матанова T. C. Ностальгичные связи, этнокультурная идентификация и евроинтеграционные взгляды среди украинских мигрантов в общине Сливен в Болгарии. В статье рассматриваются языковые, музикальные, родовые, пище-вкусовые и предметные ностальгичные связи украинских мигрантов в Сливенской общине в Болгарии. В тексте также представлены и некоторые мнения респондентов о принятии Украины в Евросоюз.

Ключевые слова: украинские мигранты; ностальгичные связи; самоидентификация; Украина в Европейском Союзе.

Matanova $T$. S. Nostalgic ties, ethnocultural identification and eurointegrational views among Ukrainian migrants in Sliven municipality in Bulgaria. The article studies the nostalgy in language, music, nutrition, kin and objects of Ukrainian migrants in Sliven municipality in Bulgaria. In the text are presented also the opinions of some respondents of the acceptance of Ukraine in the European Union.

Keywords: Ukrainian migrants; nostalgic ties; self-identification; Ukraine in the European Union.

\section{Имиграция на украинците в България}

В България се наблюдават няколко имиграционни вълни от Украйна. В периода, когато България е част от Османската империя, украинци от Кримския полуостров и Северното Причерноморие подкрепят българите във войните им за освобождение ${ }^{1}$. В първата половина на XIX в. на територията на България живеят украински казаци, а както документира паметникът на връх Шипка, имената на шест украински пехотни полка се виждат и във вградените в стените паметни плочиㄹ․ Въпреки това се смята, че първата украинска миграционна вълна, представена от незначителна група украински интелектуалци и поради което характеризирана като индивидуална и разнородна, протича в края на XIX в. ${ }^{3}$ Втората вълна, в периода между двете световни войни, т.е. след Октомврийския преврат в Русия през 1917 г. и гражданската война, е доста по-многобройна ${ }^{4}$. Въпреки че до края на XX в. тази украинска емиграция е разглеждана от българските и сьветските (руските) изследователи в по-общ план като част от белогвардейската емиграция, като част от тази вълна съставят запорожките казаци ${ }^{5}$, тя се отличава от другите етнични миграции заради използвания термин «украински» за назоваването на своите организации 6 . Третата вълна пристига в България в годините на социалистическия режим и може да бъде характеризирана като „брачна миграция“, тъй като основната причина за емиграцията в този период е сключването на брак с български граждани ${ }^{7}$. За четвърта вълна се смята трудовата и индивидуалната миграция от края на XX в., в която мигриращите са младежи с висока квалификация ${ }^{8}$.

В настоящия текст фокусът е поставен върху украинци от третата и четвъртата имиграционна вълна, живеещи в Сливен, и техните носталгични връзки, етнокултурни самоидентификации и евроинтеграционни възгледи за Украйна. 


\section{Статистически и емпирични данни}

През м. юли 2015 г. в медиите се разпространяват новини, че в Сливен „Украинци искат общински жилища... “9, че има „Три украински фирми с бизнес в Сливен“10. Оказва се, че всъщност става въпрос за около 30-40 млади украинци с бесарабско-български произход, IT-специалисти от района на Таврия и градовете Запорожие и Мелитопол, т.е. представители на четвъртата имиграционна вълна.

Статистически данни от последното преброяване на населението в България сочат, че към 1 февруари 2011 г. живеят 43 души, причисляващи себе си към украинската етнична група, от които 31 определят украинския за свой майчин език, а останалите 12 - руския език. Освен тях в преброяването са се включили и пет души с български етничен произход, но с украински майчин език. Последните има вероятност да са деца от българо-украински или бесарабско-български бракове, чиито майки са украинки и поради това са определили украинския език като майчин. Статистическите изследвания показват също, че от тези украинци 6 са родени през 30-те години на XX в., 9 - през 50-те години, 10 - през 60-те и 5 - през 70-те години на XX в. ${ }^{11} \mathrm{~B}$ община Сливен живеят и украински емигранти, които са вече с българско гражданство. По данни на отдел „Миграция““ към Областна дирекция на МВР-Сливен на територията на област Сливен към 30 септември 2015 г. пребивават 128 души, от които 81 са с право на постоянно пребиваване в страната, а 47 души са с право на продължително пребиваване. Съответно, следва последните цифри да посочват броя на в началото споменатите IT-специалисти и евентуално някои студенти от Украйна, а първите - живеещите в смесени бракове украинци и украинки.

В рамките на десет дни през февруари 2015 г. са интервюирани 11 души ${ }^{12}$, осем от които са с украински произход, двама - с българо-украински и един - с бесарабско-българо-украински произход. Тъй като в областта не съществуват нито украинско дружество, нито украински ресторант, нито украински магазин, по-голямата част от респондентите са открити чрез руското дружество в Сливен „Отчий дом“ и чрез руско-етнични близки, а другата част са техни познати или познати на запитаните украинци. Интервюираните украинци принадлежат към всички споменати възрастови групи, т.е. те са на възраст между 45 и 78 години. Само един от тях е от мъжки пол, а всички останали са жени, омъжени в България. От интервюираните 11 души по един са от Киевска, Тернополска, Полтавска и Черниговска област, а останалите са свързани с Днепропетровска и Донецка област.

\section{Носталгия и носталгични връзки с Украйна}

Незаменимостта на родината и неспособността за откъсване от своята културна и етнична обвързаност обикновено пораждат носталгични чувства в сърцето на емигранта. През XVII в. носталгията е смятана за болест ${ }^{13}$, а след XIX в. в Германия е разглеждана като гражданска добродетел. Днес културологичните науки я изследват като антропологична константа, която не зависи от културния произход на човека, а от това дали той живее като емигрант, или не ${ }^{14}$. Най-важната иे функция e, че тя му осигурява, „символично завръщане“"15 в едно определено битийно пространство“16 с качества на родина, което съживява чувствата за близост и сигурност.

Носталгията към родината, в този случай към Украйна, може да бъде проследена чрез носталгичните връзки на интервюираните украинци, съставящи и същността на тяхната носталгия. Кьм тях спадат езиковата носталгия, т.е. когато емигрантьт има желанието, но няма възможността да ползва активно майчиния си език; музикалната носталгия - когато емигрантът изпитва потребност да се наслади на традиционната фолклорна музика, която е автентична за всяка страна; родовата носталгична връзка - когато връзката със страната на месторождение е основана на семейни и родови връзки; хранително-вкусовата носталгия - която се проявява при невъзможността да се консумират любими хранителни продукти от детството, от миналото; и предметната носталгия, т.е. липсата на родни предмети и вещи от миналото.

Ако се приеме, че езиковата носталгия е налице, когато съществува желанието, но не и възможността за ползване на майчиния език в активното общуване с роднини и познати от украински произход, за четенето на книги и гледането на украинска телевизия, то сред 
запитаните такава носталгия по-скоро е рядкост. С изключение на четирима респонденти ${ }^{17}$ запитаните почти не комуникират на украински със своите близки в България и Украйна или защото не им харесва езикът, или защото в областите и в семействата, в които живеят роднините им, се говори предимно на руски език ${ }^{18}$. Прави впечатление, че те сънуват или на български, или на руски, но не и на украински език. Също така украинците държат в своите библиотеки малко български и много руски книги, последните купувани най-вече от съществуващата през социалистическо време руска книжарница в Сливен. Две от жените имат наред с руските книги по една украинска ${ }^{19}$ и само една от запитаните показа своето украинско литературно богатство - тритомно издание с творчеството на Тарас Шевченко, книги на Леся Украинка ${ }^{20}$ и на Чудомир в превод на украински език ${ }^{21}$. Факт е, че всички интервюирани гледат руска телевизия. Двама от тях си инсталират и допълнителни устройства, чрез които да могат да следят новините и филмите от украински телевизии ${ }^{22}$. Друга респондентка, напротив, не иска да гледа украински телевизии, защото не е съгласна с конфликтната ситуация в Украйна ${ }^{23}$.

Сред запитаните езиковата носталгия се проявява много повече в техните музикалноносталгични връзки с Украйна, тъй като някои от тях посещават украински интернет страници, за да намерят текстовете на украински народни песни, които да си пеят у дома или в български или руски певчески групи ${ }^{24}$, а други си носят дискове с украинска музика от Украйна ${ }^{25}$. Запитаната близо 80-годишна украинка споделя: „Когато се съберем вкъщи, песните са на първо място. Зная много украински народни песни и запознавам хората с тях. И в подходящ момент, като се вземат малко ноти, и гласът се отваря, ми казаха: „Искаме ти да пееш, а ние само да те слушаме“. Но не мога да участвам в певчески групи тука, защото не ми позволява здравето“26. На друго място тя казва: „Много харесвам украинския танц гопак, който вие българите наричате казачок. Не бих казала, че съм професионалист, но ако съм под настроение, може и да направя някоя друга стъпка“"27. Друга анкетирана украинка пък започва да танцува сама у дома: „Имаше по някаква програма украинци изпълняваха гопак и аз започнах да танцувам““28.

Родовата носталгия е слабо проявена сред запитаните, тъй като те живеят в България от дълго време, голяма част от техните роднини в Украйна са починали и се чувстват добре със създадените тук свои семейства. Някои от тях основават на тези чувства и своята представа за родина. Те споделят: „Родината е там, където семейството е заедно“ “29; „Домът ми, родината ми е там, където е семейството ми. Синът ми е моето семейство и ще бъда в държавата, в която е той“30; „България я чувствам като втора родина. Аз все си мисля, че родината на човека е там, където му са близките, семейството, хората, които обича и където той се чувства добре. Ако цялото ми семейство е тук и аз отида там, то може и да ми е мое, обаче никога няма да ми бъде достатъчно близко, и скъпо, и важно по простата причина, че не са най-скъпите хора при мен. В Украйна родителите ми починаха, но баба ми е жива и затова все още го чувствам като родина, имам брат и сестра, при които мога да си отида, а в момента, в който няма да има при кой да отида, ще спра да чувствам Украйна като родина“"31.

Традиционните ястия се оказват също съществен елемент от привързаността на човек към родината му, които той осъзнава след смяната на местопребиваването ${ }^{32}$. Това проличава ясно в отговорите и на анкетираните украинци. Едната от тях разказва: „Аз докато бях първи години тука, ревах ужасно. Беше голяма депресия, защото нямаше гречка (елда), сгущенное молоко (кондензирано мляко). Не това, че нямаше, а аз не знаех как се казва, къде да намеря. И липсваше ми много конфетьл (бонбони), пелмени, вареники и други неща, които можеш да готвиш, аз съм започнала да готвя, което в Украйна никога не съм правила. Украинское сало, сладки работи, бублики, пряники, саламче, беше ми много зле, че ги нямаше. Но сега аз намерила руски магазин в Стара Загора и София и всяка седмица се зареждам от там. Сега имам повече руски продукти, отколкото български“"33. Други респондентки споделят: „Как да не ми липсват бонбоните им, сгущенка, сметанка заквасена, майонезката тяхната не мога да я сравня с българската““34; ,Гречка много ми липсва. Много искам гречка и като я намеря, я купувам, макар и да е скъпа. И пелмени и вареники много ми се ядат ${ }^{635}$; „Аз си готвя украински борш постоянно. Той е много вкусен, не може да се сравни с руския борш. Те там някак си повече цвекло слагат и става един червен такъв. Аз също слагам цвекло, но умерено. Слагам месо, слагам картофи, зеле, черен пипер, 
дафинов лист, магданоз, копър и... нашият борш много вкусен. Правя и разсольник - супа от кисели краставички“"36. Една от интервюираните украинки, макар и да твърди, че няма хранителна носталгия, приготвя вкъщи пелмени, вареники и борш ${ }^{37}$. В дома на друга украинка се сервират винегрет, домашни вареники, пелмени и шухнудли ${ }^{38}$. Тези от запитаните, които имат възможност да пътуват до Стара Загора, се зареждат с любими храни от руския гастроном „Берьозка““39 или с подобни продукти, продавани в други хранителни вериги: „Понякога си купувам от „Кауфланд“ от италианските тестени торбички с пълнеж““40; „В София мога да си купя неща от „Берьозка“, но там много скъпо. Бонбони, които обичам от детството си, с желе и шоколадова глазура в „Берьозка“ струват 19 лева килограм. Обаче подобни бонбони има в магазин „Т-Маркет“ в Сливен, но произведени във Вилнюс, и струват 6 лева“"41. Традиционните ястия са тясно свързани и с празничния календар, тъй като те са неразривен елемент от празничната трапеза. Така за Нова година и за Різдво, което повечето интервюирани отбелязват и на 25 декември, и на 7 януари, се приготвят студень, сало, сандвичи с червен хайвер ${ }^{42}$, яйца с майонеза, т.нар. руска салата ${ }^{43}$, сарми, кисело зеле, винегрет и др. За Великден яйцата не се пишат, а се боядисват, и козунаците се пекат от респондентите, като твърдят, че различни при българския козунак и украинската паска са само формата и украсата ${ }^{44}$.

Предметната носталгична връзка или привързаността към обекти от родното място е ясно видима в присъстващите в семейното пространство картини, сувенири, книги, домакински принадлежности (уреди, готварски книги и пр.) и др. В дома на интервюираните има обери ${ }^{45}$, магнити от Украйна ${ }^{46}$, фигури на украинец и украинка, украински казак ${ }^{47}$, танцуваща гопак украинска двойка ${ }^{48}$, украинска розиис $c^{49}$, рушник $\kappa^{50}$, картина на родния град ${ }^{51}$ и други сувенири ${ }^{52}$. В кухнята се виждат и тенджера от Украйна, дъски за рязане ${ }^{53}$, самовар $^{54}$ и плетена хлебница ${ }^{55}$, а други кухненски помощници, като например уред за правене на пелмени, са прибрани в шкафовете ${ }^{56}$.

Като цяло носталгичните връзки с Украйна на запитаните украинци са изградени въз основа на индивидуални и колективни преживявания и спомени ${ }^{57}$, като те са по-силни при желанието за връщане обратно там. Това проличава в думите на две от украинките: „Иска ми се да се върна в Украйна. Спомням си всичко много добре и тъгувам по това, което нямам сега. Носталгията е неизлечима“"58. Нейната сьнародничка казва за себе си: „Преди като работех и ми беше запълнен деня беше друго. Сега като съм вкъщи много ми е мъчно за Украйна и всички наши хора. Така ми се иска да отида там. Като отида там, всяко дърво, всяка улица, всичкото е родно, моето. Всичко помня там, където играхме на улицата всякакви игри, където се катерихме по дърветата... Като отида там, все едно че съм родена наново“59. Спомените, най-вече от детските и юношеските години, съдържат не само географски и социални, но и вкусови и обонятелни пейзажи. В тази връзка една от респондентките споделя: „Ароматът е друг като минеш границата. И с влак, и със самолет като мина границата ми мирише различно, на домашно, на сладко. То няма как да се обясни. И това са ми спомените от 16-годишна възраст“60. Друга интервюирана жена казва: „Западна Украйна си я спомням с това, че там пекат много хубав черен хляб с ким. Това е ароматът, който помня от дете, и в момента направо ми мирише“"61. Тяхна сънародничка си спомня Украйна с друг аромат: „Свързвам Украйна с аромата на бял люляк. Имам хубави спомени от юношеството ми, когато цъфтеше люляка““62.

\section{Идентификации на украинците}

В отговорите на въпросите, засягащи етничното самоопределение на интервюираните, проличава, че самоидентификациите на българо-украинците са по-скоро хибридни. Единият от тях, макар и роден в украинско-българско семейство в Румъния, смята за своя родна страна България и себе си за: „Българин. 100\%. Макар че съм половината украинец, половината българин. Тогава беше руснак, тогава всичко беше руснаци в Съветския съюз“63. Другата респондентка свързва своята смесена самоидентификация с преживявания в миналото: „При мен са смесени чувствата... Аз се чувствам смесено, може би защото имам хубави спомени от тогава, когато съм била в Украйна“"64.

Почти всички запитани с украински произход смятат себе си за украинци, макар и да живеят от над 30 години в България: „Украинкой. Как могу себя другой чувствовать?/ 
Украинка. Каква иначе да се чувствам?“65; „Като българка - не. Като украинка - да““66. Тяхната идентификация с Украйна е видима и в изказванията им относно конфликтната ситуация в Украйна (актуална тема по време на провежданото проучване): „Украинка, разбира се. Сега сърцето ме боли за Украйна, че така става там. Хората толкова страдат, децата“"67; „Ама жалко, че умират невинни хора, деца. Добре, Украйна си е Украйна, но защо трябва да се отделяш? Много руснаци имало там. Ми отивайте да живеете в Русия. Русия е толкова голяма. Защо трябва да измрат толкова много хора?“68.

Някои от тях осъзнават и усвоените етнокултурни елементи и ценности на българската общност, в резултат на дългосрочното си пребиваване в България. Една от интервюираните първоначално се самоопределя като украинка: „Когато Русия атакува Украйна и хората разбрали, че има някаква разлика между Русия и Украйна... И сега всички разбират от една дума: „Не съм рускиня, а съм украинка“, но допълва впоследствие: „Нали работя в българско предприятие и ставам българка, и живея вече шест години““69. Нейна сънародничка смята, че е усвоила „чистосърдечността, доброжелателността на българите“"70. Трета респондентка сравнява себе си с българите по това, че е усвоила езика: „Даже когато се старая да говоря без акцент и не ми се налага да употребявам руски думи, някои хора не знаят, че съм рускиня. Казват: „Ти имаш същински сливенски акцент и произношение“. ... Демек, радвам се, че съм се научила добре на български и ми е лесно... и пиша на български, и говоря на български“"71. В това изказване проличава и самоидентификация с руския народ, което може да се обясни с това, че респондентката напуска своята родина, когато тя е била част от Съветския съюз, както и с това, че родният ѝ град се намира в Югоизточна Украйна, чието население е преобладаващо рускоговорящо.

На една от жените е зададен въпрос, засягащ нейната (пан)европейска идентичност ${ }^{72}$, на който тя отговаря: „Я абсолютно не считаю себя европейкой... У меня есть уже болгарское в поведении. Когда я приезжаю в Киев, мне говорят: „Что-то у тебя есть болгарское“... И потом мы пришли летом в 2014 г. ... и все знакомые и говорят: „... ты поменялась совсем. Ты вот стала такая какая-то сдержанная“. Я шучу: „Как европейцы“./ „Абсолютно не се смятам за европейка... Вече имам българско в поведението си. Когато отида в Киев, ми казват: „В теб има нещо българско“... След това бяхме там лятото на 2014 г. ... и всички познати ми казват: „...ти съвсем си се променила. Станала си някак си сдържана“. А аз се шегувам: „Като европейците“"73. На друго място тя пояснява, че има голяма разлика между живота в Европа и в България: „Сравнить как живут в Европе, как здесь живем, то мы „Як до неба пішки“, как говорят. Болгары говорят, что они европейцы. А почему же не меняете лев на евро? Пускай тогда сделают и такие зарплаты как в Европе. Европейские пенсии почему не сделают? 155 лев пенсия вообще позор“/ „Като сравниш как живеят в Европа и в България, то ние сме, както казват, „като да стигнеш до небето пеш“. Българите казват, че са европейци... Нека тогава да направят и заплатите като в Европа. Защо не направят европейски пенсии? 155 лв. пенсия е въобще позор“74. С други думи, макар и интеграцията на източноевропейски страни в Европейския съюз да означава изменението на предишни икономически, социални и политически структури ${ }^{75}$, такива са слабо осезаеми в изказванията на тази и други запитани личности. Освен това шеговитото сравнение с европейците показва, че етнокултурните, респективно националните и европейските самоидентификации не са взаимноотричащи $\mathrm{ce}^{76}$, а могат да съществуват благотворно в съзнанието на индивида, който в различни ситуации, според контекста и обостоятелствата, има възможност да избира на коя от възможното множество идентичности да даде превес.

\section{Украйна в Европейския съюз?}

В отговорите на интервюираните украинци на въпроса дали биха искали Украйна да стане част от Европейския съюз, проличават наблюдения от преживяното от тях в България след приемането ѝ в Европейския съюз през 2007 г.: „Аз им казвам: „Елате да видите какво е в България. Сега имате ли работа? Имате. Е, като влезете в Европейския съюз, няма да имате“77; „Европейският съюз нечестно постьпват. Ако бяха постьпвали честно, почтено, човешки, що да не?... Като ни приемате за членове, бъдете честни, а не ни изсмуквайте. Ето това е положението, но никой не ни пита нас“"78. Това „изсмукване“ прозвуча и в отговора на друга респондентка: „Такива магазини като „Била“, „Кауфланд“ 
и други вериги изнасят такива невероятно големи пари. Те от нас заработват милиарди, а българи... цялата печалба отива в Германия, Австрия и Евросъюза“"79.

Членството в Европейския съюз се смята от някои украинци като благотворно за пътуването извън Украйна. Тази нагласа се открива и при част от респондентите: „Може би някои неща ще бъдат по-добре, когато се влезе в Европейския съюз. Виж как тука сега свободно се движат хората без специални документи. Докато, за да отидеш в Русия и Украйна, трябва да имаш покани, няма свободно придвижване. За младите е много важно човек да може да избира къде да отиде, къде да учи“80; „Не съм сигурна. Хубавото ще е, че ще можем да си пътуваме без покани..."81, „...наши хора, украинци, възприемат Евросъюза с отмена на визи за пътуване за Евросьюз. Те са щастливи, за да пътуват някъде без визи и да идват външни коли без обмитяване... Те не разбират какви лоши ограничения има от пребиваване в Евросъюз “82.

Повечето от запитаните са против влизането на Украйна в Европейския съюз: „Что они там будут делать?/ Какво ще правят там?“683; „Нет, не хочу чтобы она входила. Нечего ей там делать. Сегодня по телевизору смотрела... Перемирие это нарушается. Там пять тысяч военных из украинской армии даже не знали что есть перемирие./ Не, не искам да влиза. Няма какво да прави там. Днес по телевизията гледах... Примирието се нарушава. Пет хиляди военни от украинската армия дори и не са знаели, че има примирие“84; , „...аз не искала Украйна да влиза в Евросъюз. Аз искала Украйна да бъде дружествена с Русия и Беларусия, защото ние сме били всички накуп и тогава бяха важни както Русия за нас, ние за Русия и Беларусия. И тези тримата държави, те са можали да бъдат много силен дружествен съюз... А ние за Евросъюз сме една такава пъпка, която ще я стиснеш и тя пропада, т.е. те няма да влагат усилия да вкарат Украйна в Евросъюз, за да ѝ дадат всички привилегии. Не вярвам. Ако на България не се стига [щом на България не дават - T. М.]. Може би, за да разсърдят повече Путин и Русия, Евросъюз ще помага на Украйна“85.

\section{Заключение}

В заключение може да бъде обобщено, че запитаните украинци най-често несъзнателно и по-скоро подтикнати от своята етнокултурна принадлежност и създадените в съответната етнокултура навици поддържат своите езикови, музикални, родови, хранителни и предметни връзки с Украйна. Като носталгични могат да бъдат наречени хранителновкусовите желания и чувството на липса на родината. Носталгията е налична, когато респондентът не се чувства щастлив със своето семейство или не е доволен от социалното си положение в България.

Относно самоидентификацията на анкетираните, при българо-украинците е ясно видима двойствената, амбивалентната идентификация, при която индивидите се отъждествяват и с двете им общности по произход ${ }^{86}$. В сравнение с тях дългогодишните украински емигранти, от една страна, запазват своята свързаност и отъждествяване с Украйна, но, от друга страна, макар и да не се самоидентифицират с българската общност, осъзнават, че са усвоили поведенчески черти и ценности, характерни за обществото домакин.

Що се отнася до евроинтеграционните възгледи на интервюираните за Украйна, те са преобладаващо негативни, което не може да се твърди за отношението им към Русия, макар и Украйна да е била част от Съветския съюз и неговите опити за русификация на говоримия език, т.е. определянето на руския език за държавен.

\section{Списьк на интервюираните}

Национален център за нематериално културно наследство (НЦНКН) при ИЕФЕМБАН, АИФ І № 483:

a.e. 1 Т. Б., украинка, р. в Николаев, от 1971 г. - Кишинев, от 1999 г. - България, пенсионер, живее в с. Скобелево, общ. Сливен

a.e. 2 Е. П., украинка, р. 1937 г. в Луганск, от 30.12.1962 г. в България, висше обр., металург, пенсионер; съпруг И. П., българо-украинец, р. в Румъния, напуска страната на 5 г., живеят в Сливен

a.e. 3 Б. Б., украинка, р. 1950 в Киев, висше обр., пенсионер 
a.e. 4 А. К., украинка, р. в гр. Кривой Рог, висше обр., мениджър обслужване, от 2009 г. в България, живее в Сливен

a.e. 5 Л. Г., баща българин, майка украинка, р. в Сливен, живее в Сливен

a.e. 6 С. Г., украинка, p. 1940 г. в Енакиево (Донецка област), от 1960 г. живее в Сливен

a.e. 7 Л. С., украинка, p. 1952 в Креминец, Тернополска област, живее в Сливен от края на 1970-те години

a.e. 8 К. С., украинка, р. в гр. Каменка (Днепропетровска област), висше обр., инженер, от 1982 г. в България, живее в Сливен

а.е. 9 Т., украинка, висше обр., инженер, собствен бизнес

a.e. 10 М. С., бесарабско-българо-украинка, висше обр. в България, от 1990 г. в България, живее в Сливен

a.e. 11 Г. Б., р. в Полтава, от 1989 г. в България, висше обр., учителка, живее в Сливен.

${ }^{1}$ Савов Н. Паметник на украинските воини // Паметник. Паметниците на Варна. Варна: Агенция Барс, 2007. - С. 251-252.

2 Дойнов Сm. Руско-турската освободителна война (1877-1878) висторическата съдба на българския народ // Българистика. Информационен бюлетин. - 2008. - № 16. - С. 10; Савов Н. Паметник на украинските воини ... - С. 252.

3 Якімова А. Українці в Болгарії: філософія історичного буття. - София, 2011. - С. 53.

${ }^{4}$ Бильк $A$. Актуальное интервью. Болгарские украинцы на пути объединения. Украинское национальное информационное агенство - УКРИНФОРМ. - 2006. - URL: http://www.ukrinform.ua/rus/ order/?id=48054 (посетен: 4.03.2011).

5 Якімова А. Українці в Болгарії... - С. 34; Пръв по рода си документален каталог [,Украинската емиграция в България след Първата световна война“] събра в София българи и украинци „под една шапка“"/ Демокрация. - 2001. - № 155. - С. 18.

${ }^{6}$ Кьосева Цв. Русская эмиграция в Болгарии // Русское слово. - 2001. - № 3. - С. 2.

${ }^{7}$ По това време в Украйна учат и работят много българи.

${ }^{8}$ Якімова А. Українці в Болгарії... - С. 94.

${ }^{9}$ Украинци искат общински жилища. Щяло да им е по-евтино // Сливен прес. - 2015. - 13 юли. URL: http://www.slivenpress.bg/novini-sliven/ 15264-УКРАИНЦИ-ИСКАТ-ОБЩИНСКИ-ЖИЛИЩАЩЯЛО-ДА-ИМ-Е-ПО-ЕВТИНО (посетен на 18.08.2015).

${ }_{10}$ Три украински фирми с бизнес в Сливен // Дарик нюз. - 2015. 12 септември. - URL: http:// dariknews.bg/print_article.php?article_id=1497885 (посетен на 18.08.2015).

11 Трябва да се има предвид, че в преброяването въпросите за самоопределянето на майчиния език и етничната група са доброволни, т.е. може да има и такива, които не са отговорили на тези въпроси.

12 Теренните материали са събрани за изпълнение на индивидуалните задачи по Проект „Конструиране на идентичността в контекста на пан-европейска мобилност (украинците в България и българите в Украйна)“ между ИЕФЕМ-БАН и Института за изкуствознание, фолклористика и етнология „М. Т. Рилски“ към НАНУ. Аудиозаписите, фотоматериалите и част от дешифрамите на проведените интервюта са архивирани в НЦНКН при ИЕФЕМ-БАН с архивни номера: Фоноархив на Института за фолклор (по-нататьк - ФнАИФ) № 2713, Фотоархив на Института за фолклор (понататък - ФтАИФ) № 1413 и Архив на Института за фолклор (по-нататък - АИФ) I № 483.

${ }^{13}$ Greverus I.-M. Heimweh und Tradition // Schweizerisches Archiv für Volkskunde. - 1965. - № 61. - S. 1-31; Zwingmann Ch. Das nostalgische Phänomen // Zur Psychologie der Lebenskrisen. - Frankfurt am Main, 1962. - S. 308-338.

${ }^{14}$ Dietzel-Papakyriakou M. Heimweh bei alten Migranten: Die Sehnsucht nach der Heimat ist auch eine Sehnsucht nach dem Raum / Y. Karakaşoğlu, J. Lüddecke (Hg.) // Migrationsforschung und interkulturelle Pädagogik. Aktuelle Entwicklungen in Theorie, Empirie und Praxis. - Münster, 2004. - S. 31.

${ }_{15}$ Zwingmann Ch. Das nostalgische ... - S. 315.

${ }^{16}$ Greverus I.-M. Auf der Suche nach Heimat. - München, 1979. - S. 112.

${ }^{17} Ф_{н}$ АИФ № 2713, a.e. 13; ФН АИФ № 2713, a.e. 12; Фн АИФ № 2713, a.e. 11; Фн АИФ № 2713 , a.e. $6-7$.

${ }^{18}$ Последното изследване на социологическата група „Рейтинг“, извършено във всички областни центрове без Крим и Донбас през м. март 2015 г., относно езика, използван в семейна среда от гражданите на Украйна, включва отговорите на 17000 запитани. Според него областните центрове, в които украинският език е ползван за общуване в семейството при над 90\% от запитаните, са Луцьк/ Луцк и Рівне/ Ровно, Львів/ Лвов, Івано-Франківськ/ Ивано-Франковск и Тернопіль/ Тернопол. В сравнение с това над 55\% от жителите на Харків/ Харков, Одеса, Миколаїв/ Николаев, Запоріжжя/ 
Запорожие и Дніпропетровськ/ Днепропетровск предпочитат да говорят на руски вкъщи (за повече информация вж. Рух добровольців. «Простір свободи». Становище української мови в Україні в 2014-15 роках. Аналітичний огляд. Рух добровольців «Простір свободи». - 2015. - URL: http:// dobrovol.org/files/2015/stan_movy_2014_15.doc

${ }^{19}$ ФН АИФ № 2713, а.е. 12; АИФ I № 483, a.e. 9.

${ }^{20}$ ФТАИФ № 1413 , a.e. 48-50.

${ }^{21}$ Фн АИФ № 2713, a.e. 6-7.

${ }^{22}$ Фн АИФ № 2713, a.e. 1, АИФ I № 483, a.e. 1.

${ }^{23}$ АИФ I № 483, a.e. 9.

${ }^{24}$ Фн АИФ № 2713, a.e. 13-14; Фн АИФ № 2713, a.e. 15.

${ }^{25}$ ФН АИФ № 2713, a.e. 11.

${ }^{26}$ АИФ I № 483, a.e. 2 .

${ }^{27}$ АИФ I № 483, a.e. 2 .

${ }^{28}$ АИФ І № 483, a.e. 3 .

${ }^{29}$ АИФ I № 483, a.e. 8 .

${ }^{30}$ АИФ I № 483, a.e. 3.

${ }^{31}$ АИФ I № 483, a.e. 10 .

${ }^{32}$ Weiß R. Volkskunde der Schweiz. Grundriss. - Erlenbach-Zürich, 1946. - S. 132-133.

${ }^{33}$ АИФ I № 483, a.e. 4.

${ }^{34}$ АИФ I № 483, a.e. 4 .

${ }^{35}$ АИФ I № 483, a.e. 7 .

${ }^{36}$ АИФ I № 483, a.e. 6 .

${ }^{37}$ Фн АИФ № 2713, a.e. 6-7.

38 Шухнудли - варени нарязани парчета навито на руло тесто като за вареники (вж. ФТАИФ № 1413, a.e. 53).

${ }^{39}$ ФТАИФ № 1413, a.e. 3.

${ }^{40}$ АИФ І № 483, a.e. 7.

${ }^{41}$ АИФ I № 483, a.e. 11.

${ }^{42}$ Фн АИФ № 2713, a.e. 13 .

43 АИФ І № 483, а.е. 5 .

${ }^{44}$ Вж. Фн АИФ № 2713, a.e. 6-7, Фн АИФ № 2713, a.e. 13, Фн АИФ № 2713, a.e. 15.

${ }^{45}$ ФТАИФ № 1413, a.e. 1 .

${ }^{46}$ ФТАИФ № 1413, a.e. 4, 11.

${ }^{47}$ ФТАИФ № 1413 , a.e. 16.

${ }^{48}$ ФТАИФ № 1413, a.e. 52.

${ }^{49}$ ФТАИФ № 1413, a.e. 15.

${ }^{50}$ ФТАИФ № 1413, a.e. 43.

${ }^{51}$ ФТАИФ № 1413, a.e. 31.

52 ФТАИФ № 1413, a.e. 28.

${ }^{53}$ ФТАИФ № 1413, a.e. 37.

${ }^{54}$ ФТАИФ № 1413, a.e. 24.

${ }^{55}$ ФТАИФ № 1413, a.e. 9.

${ }^{56}$ Вж. ФНАИФ № 2713, a.e. 15.

57 Относно индивидуалните и колективните носталгични форми вж. Dietzel-Papakyriakou M. Heimweh bei alten Migranten... - S. 30.

${ }^{58}$ АИФ I № 483, a.e. 8 .

${ }^{59}$ АИФ I № 483, a.e. 7.

${ }^{60}$ АИФ I № 483, a.e. 5 .

${ }^{61}$ АИФ I № 483, a.e. 10 .

${ }^{62}$ АИФ I № 483, a.e. 11.

${ }^{63}$ АИФ I № 483, a.e. 2.

${ }^{64}$ АИФ І № 483, a.e. 5.

${ }^{65}$ АИФ I № 483, a.e. 1 .

${ }^{66}$ АИФ І № 483, a.e. 7.

${ }^{67}$ АИФ I № 483, a.e. 6.

${ }^{68}$ АИФ І № 483, a.e. 7 .

${ }^{69}$ АИФ І № 483, a.e. 4.

${ }^{70}$ АИФ I № 483, a.e. 8 .

${ }^{71}$ АИФ I № 483, a.e. 6 .

72 Повече за (пан-)европейската идентичност вж. в: Jacobs D. European Identity: Construct, Fact and Fiction / Dirk Jacobs, Robert Maier // M. Gastelaars, A. de Ruijter (eds.) // United Europe. The Quest for a Multifaceted Identity. - Maastricht: Shaker, 1998. - P. 13-34; Cinpoes R. From National Identity to European Identity // Journal of Identity and Migration Studies. - 2008. - № 2 (1). - P. 3-14; White T. R. 
European Integration, Identity, and National Self Interest: The Enduring Nature Of National Identity. Political Science Department // Theses, Dissertations, and Student Scholarship. - Paper 6. - 2010. - URL: http://digitalcommons.unl.edu/poliscitheses/6 (посетен на 20.02.2016).

${ }_{73}^{7}$ АИФ І № 483, a.e. 3 .

${ }^{74}$ АИФ І № 483, a.e. 3.

${ }^{75}$ Angulo M. I. Nationan Building within the European Union: Reframing Bulgarian National Identity from Abroad // Dynamics of National Identity and Transnational Identities in the Process of European Integration / E. Marushiakova (ed.). - Cambridge Scholars Publishing, 2008. - P. 155; Hristov P. Migration Strategies and Malleable Identities among Bulgarian Youths in the Odessa District / P. Hristov, A. Kasabova, E. Troeva, D. Demski (Eds.) // Contextualizing Changes: Migration, Shifting Borders and New Identities in Eastern Europe. - Sofia: Paradigma Publishing House, 2015. - P. 141.

${ }^{76}$ Вж. Cinpoes $R$. From National Identity to European Identity... - P. 8.

${ }^{77}$ АИФ І № 483, a.e. 2.

${ }^{78}$ АИФ І № 483, a.e. 2.

${ }^{79}$ АИФ I № 483, a.e. 4 .

${ }^{80}$ АИФ I № 483, a.e. 6.

${ }^{81}$ АИФ I № 483, a.e. 5.

${ }^{82}$ АИФ І № 483, a.e. 4.

${ }^{83}$ АИФ І № 483, a.e. 1.

${ }^{84}$ АИФ І № 483, a.e. 3.

${ }^{85}$ АИФ І № 483, a.e. 4.

${ }^{86}$ Вж. Penchev V. Folklore as a factor of (bi)identity // Македонски фолклор. - Т. 58-59. - Скопје, 2001. - P. 129-134. 